\title{
PENGARUH PEMBERIAN MASASE ENDORFIN TERHADAP INTENSITAS NYERI PADA PROSES PERSALINAN FISIOLOGIS
}

\author{
Effects of Endorphin Masage on Pain Intensity in Physiological Labor Process
}

\author{
NMR Sumawati ${ }^{1}$ Putu Mastiningsih ${ }^{1}$

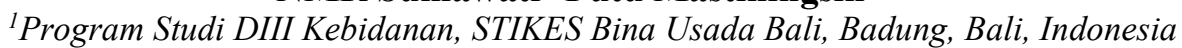 \\ Korespondensi : maderisna@ymail.com
}

\begin{abstract}
ABSTRAK
Kelancaran suatu persalinan sangat dipengaruhi oleh penanganan yang baik selama proses persalinan. Pengurangan nyeri persalinan dengan endorfine massage merupakan salah satu metode non farmakologis yang bisa digunakan. Tujuan penelitian ini adalah untuk mengetahui pengaruh teknik endorfin massage terhadap intensitas nyeri pada proses persalinan fisiologis. Populasi target dalam penelitian ini adalah seluruh ibu bersalin di BPM Putu Mastiningsih. Jumlah sampel pada penelitian ini sebanyak 16 dengan teknik sampel consecutive sampling. Jenis penelitian ini menggunakan analitik observasi dengan menggunakan praeksperimen dengan rancangan penelitian one group pretest postest. Analisa data menggunakan uji paired-t. Hasil penelitian ini adalah ada pengaruh teknik endorfin massage terhadap proses persalinan fisiologis.
\end{abstract}

Kata Kunci : nyeri, endorfin massage, persalinan

\section{ABSTRACT}

The success of a labor process is strongly influenced by good handling during the labor process. Reduction of labor pain with endorfine massage is one of the non-pharmacological methods that can be used. The purpose of this study was to determine the effect of endorfin massage on pain intensity in physiological labor. The target population in this study were all women giving birth at BPM Putu Mastiningsih. The number of samples in this study were 16 with consecutive sampling technique. This type of research uses observational analytics using pre-experimental research designs with one group pretest posttest. Data analysis uses paired-t test. The results of this study are that there are effects of endorphin massage on pain intensity in physiological labor.

Keywords: pain, endorfin massage, labor 


\section{PENDAHULUAN}

Persalinan normal merupakan proses alamiah bagi semua wanita. Persalinan normal atau sering disebut dengan persalinan alamiah dalam prosesnya diawali dengan adanya dilatasi servik yang ditandai dengan adanya kontraksi uterus kemudian lahirnya bayi dan diikuti dengan lahirnya plasenta. Bagi wanita yang pertama kali akan mengalami proses ini tentu saja merupakan hal baru Melahirkan bayi mungil yang menggemaskan menjadi dambaan setiap ibu hamil. Namun dalam kenyataannya impian kebahagiaan itu menjadi terganggu oleh karena bayangan tentang persalinan yang menakutkan.

Studi pendahuluan yang diperoleh dari hasil wawancara dengan bidan yang menangani persalinan di BPM Putu Mastiningsih menyampaikan bahwa, dalam 1 bulan rata- rata jumlah ibu yang bersalin adalah 30 orang. Hampir semua ibu yang bersalin belum dapat mengontrol nyeri dengan baik, artinya sebagian besar ibu yang bersalin masih tidak tenang selama proses bersalin, bahkan ibu yang tidak mau melahirkan normal pada persalinan berikutnya akibat trauma rasa nyeri pada persalinan sebelumnya.

Teknik masase endorfin merupakan metode yang baik digunakan untuk mengurangi nyeri selama persalinan. Sampai sejauh ini belum ada penelitian yang mengkombinasikan kedua teknik tersebut, sehingga mendorong peneliti untuk menilai penggabungan kedua metode tersebut.

\section{TUJUAN PENELITIAN}

Penelitian ini bertujuan untuk mengalisis pengaruh pengaruh teknik masase endorfin terhadap intensitas nyeri pada proses persalinan fisiologis

\section{METODE PENELITIAN}

Desain

Jenis penelitian ini menggunakan analitik observasi dengan menggunakan praeksperimen dengan rancangan penelitian one group pretest postest

\section{Populasi dan Sampel}

Populasi target dalam penelitian ini adalah seluruh ibu hamil yang bersalin di
BPM Putu Mastiningsih. Sampel dalam penelitian ini ditentukan dengan teknik concecutive sampling. Jumlah sampel pada penelitian ini sebanyak 16 orang.

\section{Tempat dan Waktu Penelitian}

Penelitian dilaksanakan di BPM Putu Mastiningsih. Pengambilan data dilakukan selama 4 minggu.

\section{Intervensi}

Pemberian intervensi masase endorfin dilakukan selama 6 minggu setiap satu klai dalam satu minggu. Masase dilakukan selama 30 menit.

\section{Instrumen dan Prosedur Pengukuran \\ Instrumen yang digunakan pada pengukuruan variabel adalah pain visual analague scale.}

\section{Analisa Data}

Data yang dikumpulkan pada penelitian ini berupa data primer karena pengumpulan data dilakukan secara langsung terhadap responden dengan menggunakan alat pengukuran atau alat pengambilan data langsung pada subjek sebagai sumber informasi yang dicari Analisa univariat dilakukan pada data karakteristik responden dan kepatuhan pasien.

\section{HASIL PENELITIAN}

Adapun gambaran distribusi responden pada BPM Mastiningsih yaitu sebagai berikut:

Tabel 1

Karakteristik Responden $(\mathrm{n}=16)$

\begin{tabular}{lcc}
\hline \multicolumn{1}{c}{ Variabel } & $\mathrm{n}$ & $\%$ \\
\hline Usia & & \\
$<20^{\text {th }}$ & 1 & 6 \\
$20-35^{\text {th }}$ & 11 & 69 \\
$\quad>35^{\text {th }}$ & 4 & 25 \\
Lama Persalinan Kala II & & \\
$\quad<2$ jam-2 jam & 16 & 100 \\
$\quad>2$ jam & 0 & 0 \\
\hline
\end{tabular}

Berdasdarkan tabel 1 menunjukkan usia responden didominasi pada rentang usia 20-35 tahun, dengan lama persalinan kala II $100 \%$ pada kurun waktu kurang dari 2 jam sampai 2 jam. 
Tabel 2

Intesitas Nyeri Pada Ibu Hamil $(\mathrm{n}=16)$

\begin{tabular}{lccccc}
\hline \multicolumn{1}{c}{ Variabel } & $\mathrm{n}$ & $\%$ & $\begin{array}{c}\mathrm{Me} \\
\mathrm{an}\end{array}$ & $\mathrm{SD}$ & $\begin{array}{c}\mathrm{p}- \\
\text { value }\end{array}$ \\
\hline Intensitas Nyeri & & & & & \\
Sebelum Intervensi & 3 & 19 & & & \\
$\quad$ Nyeri Ringan & 6 & 38 & 7,4 & 1,50 & \\
$\quad$ Nyeri Sedang & 7 & 44 & & & \\
$\quad$ Nyeri Berat & & & & & 0,01 \\
Intensitas Nyeri & & & & & \\
Setelah Intervensi & 3 & 19 & 3,8 & 1,82 & \\
$\quad$ Nyeri Ringan & 12 & 75 & & & \\
$\quad$ Nyeri Sedang & 1 & 6 & & & \\
$\quad$ Nyeri Berat & & & & & \\
\hline
\end{tabular}

Berdasarkan tabel 2 menunjukkan bahwa dari 16 responden sebagian besar reponden mengalami nyeri berat sebelum dilakukan masase endorfin sebesar 44 menurun menjadi nyeri sedang sebesar $75 \%$ sesudah dilakukan masase endorfin . Banyak ditemui pada responden yang mempunyai ambang nyeri yang tinggi sehingga tidak kuat menahan nyeri yang dirasakan.

Hasil perhitungan dapat disimpulkan bahwa responden sebagian besar mengalami penurunan nyeri berat menjadi nyeri sedang. Tabel diatas juga menyatakan bahwa $\mathrm{p}$ value $=0,000$, hal ini menunjukan bahwa ada pengaruh masase endorfin terhadap intensitas nyeri kala I dan lama persalinan pada ibu primipara di BPM Putu Mastiningsih.

\section{PEMBAHASAN}

Mekanisme persalinan yang terjadi pada responden dapat memodifikasi dan merubah sensasi nyeri yang datang sebelum mereka sampai di kortek serebri sehingga menimbulkan persepsi nyeri. Serabut kecil mentransmisikan sensasi nyeri yang keras yang mempunyai reseptor berupa ujung- ujung saraf bebas di kulit dan struktur dalam seperti tendon, otot dan alat-alat dalam. Sedangkan serabut besar mentransmisikan sensasi sentuhan, getaran, suhu hangat dan tekanan halus (Crisp \& Taylor, 2012).

Menurut Mander, (2006) bahwa tindakan utama massage dianggap menutup gerbang untuk menghambat perjalanan rangsang nyeri pada pusat yang lebih tinggi pada system saraf. Selanjutnya, rangsangan taktil dan perasaan positif, yang berkembang ketika dilakukan bentuk sentuhan yang penuh perhatian dan empatik, bertindak memperkuat efek masase untuk mengendalikan nyeri.

Endorfin memengaruhi transmisi impuls yang diinterprestasikan sebagai rasa nyeri. Endorfinm dapat berupa neurotransmitter yang dapat menghambat transmisi atau pengiriman pesan nyeri (Bahrudin, 2017). Keberadaan endorfin pada sinaps sel saraf menyebabkan penurunan sensasi nyeri (Rokade, 2011). Kadar endorfin berbeda antara satu orang dengan orang lain. Orang yang memiliki kadar endorfin tinggi lebih sedikit mengalami nyeri, dan sebaliknya orang yang memiliki kadar endorfin rendah akan mengalami tingkat nyeri yang sangat tinggi (Setyowati, Diana, \& Mafticha, 2015). Beberapa tindakan pereda nyeri dapat bergantung pada endorfin yang dapat dilakukan dengan cara masase di daerah tubuh yang dapat merangsang atau melepaskan hormon endorfin untuk mengurangi nyeri (Reeder \& Koniak, 2012)

Responden yang diberikan masase endorfin sebagian besar mengalami penurunan skala nyeri. Keadaan responden sebelum dilakukan masase endorfin mengalami nyeri yang hebat atau tidak tertahankan. Setelah diberikan massae endorfin, sebagian besar responden mengalami perubahan nyeri, pijatanpijatan halus masase endorfin dilakukan pada bagian-bagian tubuh yang dapat merangsang hormon endorfin sehingga menghambat penggiriman pesan nyeri.

Menurut Mongan, (2015) menyatakan bahwa endorfin dapat meningkatkan pelepasan zat oksitosin, sebuah hormon yang memfasilitasi persalinan sehingga dapat mengurangi rasa nyeri. Masase endorfine dapat mengatur produksi hormon pertumbuhan dan seks, mengendalikan rasa nyeri serta sakit yang menetap, mengendalikan perasaan stres, serta meningkatkan sistem kekebalan tubuh (Elvira \& Tulkhair, 2018). 


\section{KESIMPULAN}

Implikasi

Terdapat pengaruh pemberian teknik endorfin massage terhadap intensitas nyeri pada persalinan fisiologis. Hasil penelitian ini diharapkan tenaga kesehatan dapat menerapkan metode pengendalian nyeri non-farmakologis teknik masase endorfin kepada pasien untuk mengurangi tingkat nyeri yang dirasakan selama inpartu kala I fase aktif pada persalinan sehingga persalinan menjadi lebih lancar

\section{Keterbatasan}

Penelitian ini menggunakan jumlah sampel yang relative sangat kecil dan dilakukan pada satu BPM sehingga hasil penelitian ini tidak dapat digeneralisasi pada populasi ibu dengan persalinan fisiologis.

\section{DAFTAR PUSTAKA}

Bahrudin, M. (2017). Patofisiologi Nyeri (Pain). Sainmed, 13(1), 7-13.

Crisp, J., \& Taylor, C. (2012). Potter \& Perry's Fundamentals of Nursing (3rd ed.). Jakarta: EGC.

Elvira, M., \& Tulkhair, A. (2018). Pengaruh Pijat Endorphine Terhadap Skala Nyeri Pada Siswi SMA Yang Mengalami Disminore. Jurnal IPTEK Terapan, 12(2), 155-166.

Mander, R. (2006). Nyeri Persalinan. Jakarta: EGC.

Mongan, M. F. (2015). Hypnobirthing: The Mongan Method. Jakarta: Bhuna Ilmu.

Reeder, M., \& Koniak, G. (2012). Keperawatan Maternitas: Kesehatan Wanita, Bayi, dan Keluarga (18th ed.). Jakarta: EGC.

Rokade, P. B. (2011). Release of Endomorphin Hormone and Its Effects on Our Body and Moods: A Review. In International Conference on Chemical, Biological and Environment Sciences (Vol. 431127, pp. 436-438).

Setyowati, D., Diana, S., \& Mafticha, E. (2015). Pengaruh Endorphin Massage Terhadap Intesitas Nyeri Kala I Fase Aktif Pada Persalinan di RSU Dr Wahidin Sudiro Husodo Kota Mojokerto. Pekarungan. 